\title{
Operational Parameters Assessment of a Biomass-To-Fuel Gas Converter
}

\author{
K.H.Chong, P.L Law, A.R.H. Rigit, R.Baini, S.F.Saleh and A. A. R. Awangku Yussuf
}

\begin{abstract}
This study presents the assessment on the existing mini-sized biomass-to-fuel gas (B2F) converter. Operational parameters, such as composition of after filtered residual liquid (AFRL), composition of raw combustible fuel gases produced using wood chips and coal as feedstock, and nearby incremental levels of carbon monoxide and suspended particulate during operation, are determined. Analysis results of the raw (unburnt) combustible fuel gases from low grade Balingian-Mukah coal and wood chips found that there were approximately $23-29 \%$ gasoline constituents; $15-30 \%$ diesel constituents; $1-16 \% \mathrm{CO}_{2} ; 10-13 \% \mathrm{O}_{2}, \mathrm{CO}, \mathrm{SO}$, NO and $\mathrm{H}_{2} \mathrm{O} ; 46-71 \%$ combustible gases. It was observed that the phenol contained in the AFRL recorded approximately $5,310 \mathrm{mg} / \mathrm{L}$. Moreover, by-products, such as $1.5 \%$ tars and $13 \%$ AFRL, were produced. The result shows that a B2F converter is suitable to harvest the combustible gases that can be used as fuel for internal combustion engines. However, the amount of organics indicated that the AFRL should not be discharged directly into watercourses without pre-treatment.
\end{abstract}

Keywords: Gasification, Combustible gas, Coal, Wood chips

\section{INTRODUCTION}

In Malaysia's logging industries in 2009, wood waste alone gave a total production of logs, based on the total land area, of 18.27 million $\mathrm{m}^{3}$ [1]. From January to February 2009, Malaysia generated a free on board (FOB) value of more than RM 202 million through logging activities [2]. This generated a huge amount of wood waste that, potentially, could have given rise to sensitive environmental disposal issues. In 2013, the total current energy demand in Malaysia was 33.9 Mtoe; by 2020 , the energy demand is expected to grow by $5.4 \%$ per annum to reach 83.5 Mtoe [3]. It is estimated that the oil reserves in Malaysia will last for 15 years and gas reserves for another 29 years [4]. Although efforts at renewable energy have been initiated by the Malaysian government, the response has not been positive [5]; regardless, renewable energy still has great growth potential.

It is well-known that gasification is a comparatively cheap method that can produce product gas with very low tar content [6]. According to Walawender's study of a model of gasifier (stratified and open top), the average composition of the gas on a dry basis is as thus: $\mathrm{H}_{2}=15.1 \% ; \mathrm{CO}=19.1 \% ; \mathrm{CH}_{4}=2.5 \% ; \mathrm{CO}_{2}=15.8 \%$; small quantities of $\mathrm{C}_{2} \mathrm{H}_{6}, \mathrm{C}_{2} \mathrm{H}_{2}$ and $\mathrm{C}_{3} \mathrm{H}_{4}$ and the remainder is $\mathrm{N}_{2}$ [7]. Garcia-Bacaicoa built two stratified-closed top gasifiers: one for $50 \mathrm{~kg} / \mathrm{h}$ and another for $200 \mathrm{~kg} / \mathrm{h}$ of the same configuration. The average composition of the gas produced on a dry basis is in the following range of volume percentage: $\mathrm{N}_{2}=45-60 \% ; \mathrm{CH}_{4}=0.25-2.5 \% ; \mathrm{H}_{2}=10-22 \% ; \mathrm{CO}=13-25 \% ; \mathrm{CO}_{2}=8-19 \%$ and traces of $\mathrm{C}_{2} \mathrm{H}_{2}$ and $\mathrm{C}_{2} \mathrm{H}_{4}[8]$. In addition, the burning of biomass will introduce chemicals, such as polycyclic aromatic compounds (PAC) and heavy metals [9].

To date, various types of biomass combustor are available, such as updraft, downdraft, cross-draft, fluidised-bed design features and others [10]. However, treatment technologies for gasification in terms of cost-effectiveness, local availability and serviceability of materials and equipment that require low technical skills for operation and maintenance are not available [11]. Therefore this study aims to investigate the feasibility of a B2F converter for fuel production.

\section{A. B2F Converter}

A B2F converter (Figure 1) at the $12^{\text {th }}$ Mile Oya Road, Sibu (Malaysia) was developed, constructed and tested for drying and heating purposes in commercialised industrial scale applications, the mushroom culture industry, egg tray manufacturing facilities, powdered coconut milk production, and paper recycling facilities. For this system, solid feedstock (wood chips

Chong, K.H.,Student, Department of Mechanical Engineering, Faculty of Engineering, Universiti Malaysia Sarawak, Malaysia, isaackokhing@gmail.com

Law, P.L., Lecturer, Department of Civil Engineering, Faculty of Engineering, Universiti Malaysia Sarawak, Malaysia, puonglaw@ feng.unimas.my Rigit, A.R.H ,Lecturer, Department of Mechanical Engineering, Faculty of Engineering, Universiti Malaysia Sarawak, Malaysia arigit@ feng.unimas.my Baini, R. , Lecturer, Department of Chemical Engineering and Energy Sustainability, Faculty of Engineering, Universiti Malaysia Sarawak, Malaysia, ruby@feng.unimas.my

Shanti, F.S., Lecturer, Department of Chemical Engineering and Energy Sustainability, Faculty of Engineering, Universiti Malaysia Sarawak, Malaysia, sshanti@feng.unimas.my

Awangku Yusof, A.R.B.P.H., Lecturer, Faculty of Science and Technology, Universiti Science Islam Malaysia, Malaysia, awangku2011@usim.edu.my 
and Balingian-Mukah coal) are gasified in the updraft B2F converter, and the fuel gas or combustible gas is produced by air mixture to maximise the efficiency of the gasification process. The fuel gas is purified by filtration process before being used as low-medium heat value fuel for heating and drying purposes.

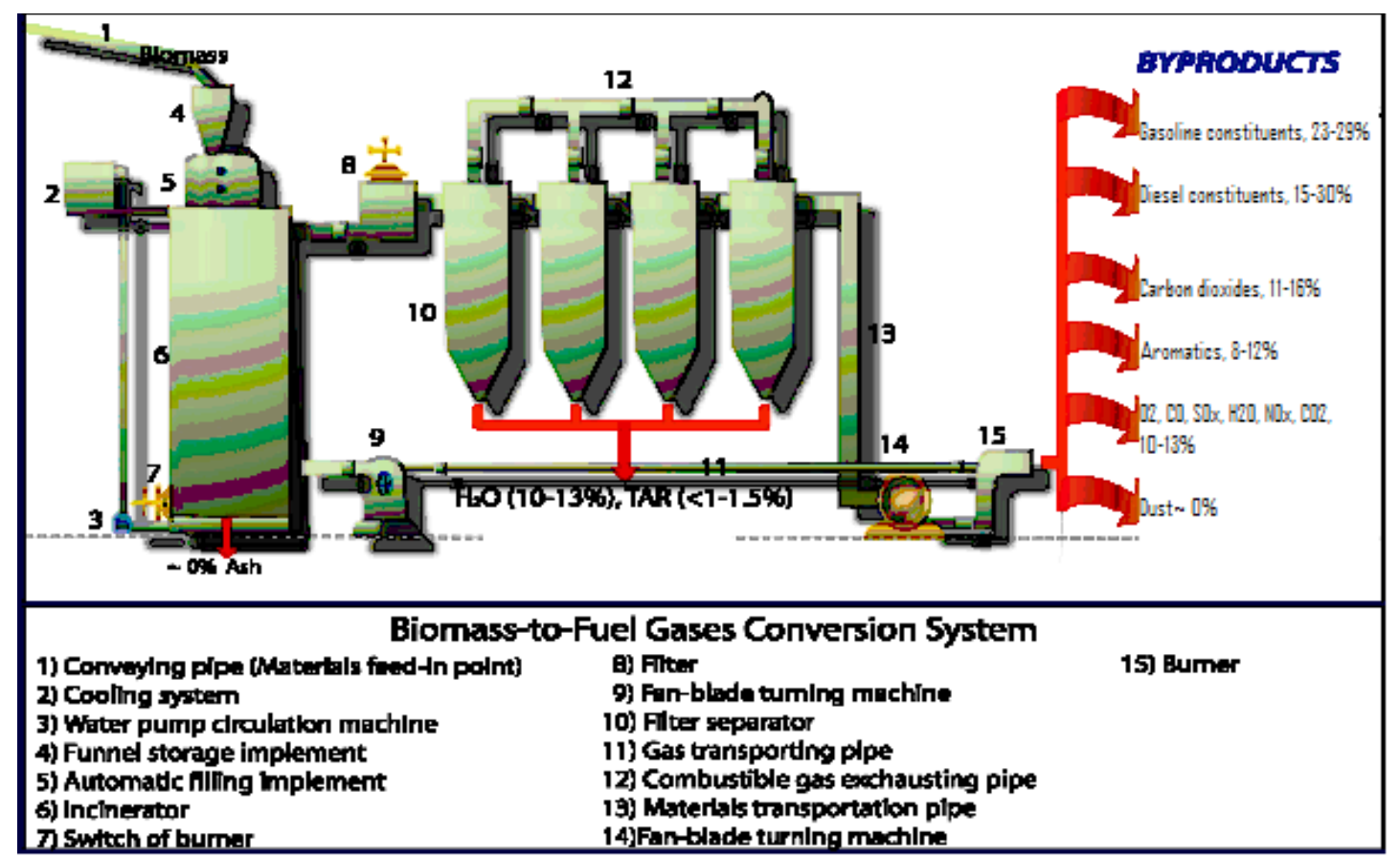

Figure 1: Simplified schematic diagram of B2F converter

\section{B. Components of B2F Converter}

A B2F consists of various components. The incinerator comprises of a layer of fire-proof brick as the inner wall and is surrounded by a layer of water compartment. A B2F converter is equipped with an incinerator, which includes an ash collection (Figure 2). A plurality of air inlets at the bottom and upper of incinerator are introduced to enhance pyrolysis and combustion conversion. In addition, the $\mathrm{B} 2 \mathrm{~F}$ converter is equipped with filters connected to the incinerator by a gas conveying pipe (Figure 3). The filters of the B2F converter are equipped with the following features (Figures 3): (1) an inlet connected with a gas conveying pipe, (2) an internal vertical duct at the middle of the filter, and (3) an outlet connection at the upper part of the internal vertical duct to direct the filtered gas for usage. The internal vertical duct of the filter is made up of a wider dimensional opening at the bottom end and forms a conical shape duct, as it moves further up before the vertical duct (Figure 3). There is an external chamber with a tap for removal of overflowed liquid in the filters (Figure 4). Finally, the incinerator includes an upper gas storage case for storing combustible gas before sending it to the gas conveying pipe.

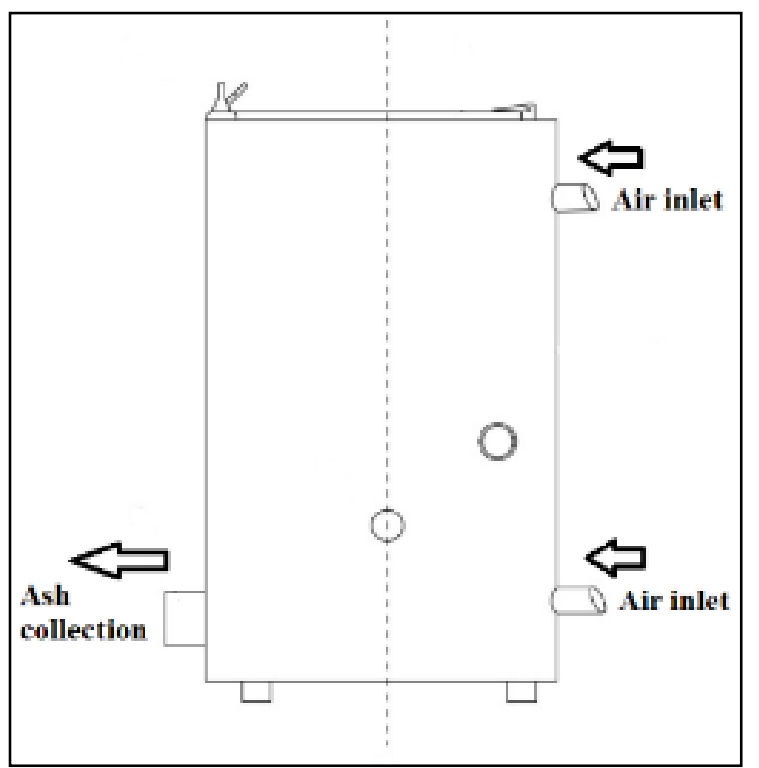

Figure 2: Cross-sectional illustration of a B2F converter 


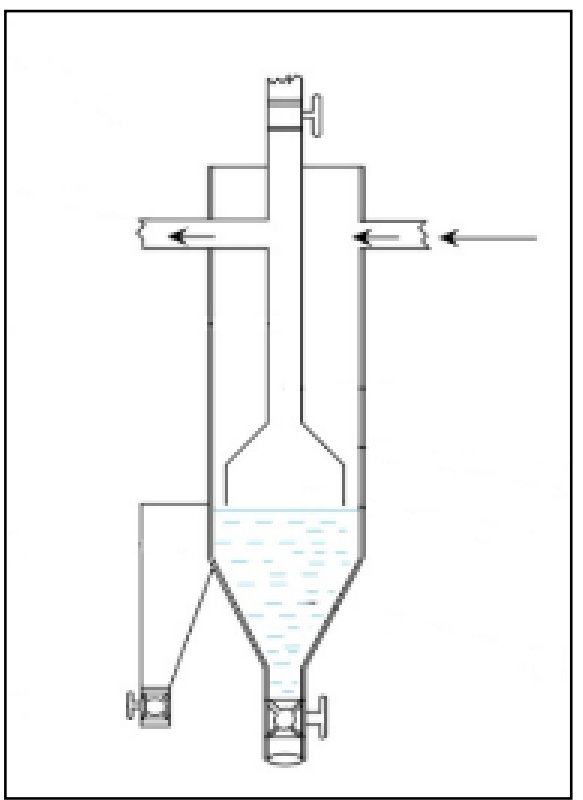

Figure 3: Cross-sectional view of a filter unit

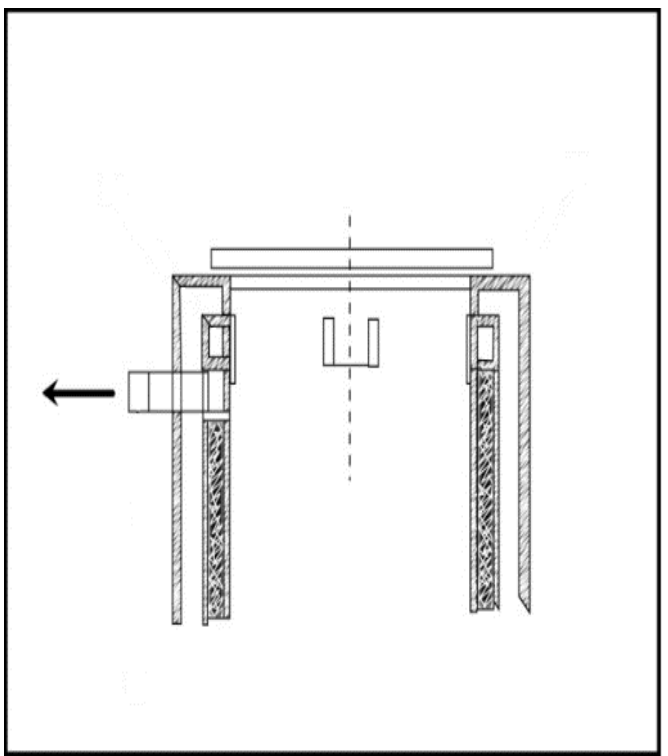

Figure 4: Cross-sectional view of the top part of a B2F converter

\section{MATERIAL AND METHODS}

\section{A. Condensate AFRL measurement}

Samples of the condensate AFRL, collected from the bottom of the filters, were analysed with a gas chromatography mass spectrometer (GCMS) (Model: Hewlett Packard HP 5890 Series II Plus). The analysed chemical composition of the samples (wood and coal) included the following.

- Inorganic analysis-Acid digest according to APHA 3030E and heavy metals ( $\mathrm{Sb}, \mathrm{As}, \mathrm{Ba}, \mathrm{Be}, \mathrm{Cd}, \mathrm{Cr}, \mathrm{Co}, \mathrm{Cu}, \mathrm{Pb}$, $\mathrm{Mo}, \mathrm{Ni}, \mathrm{Se}, \mathrm{Ag}, \mathrm{V}, \mathrm{Zn}, \mathrm{B}$ and $\mathrm{Fe}$ ) analysis according to SW $846610 \mathrm{~B}$.

- Mercury analysis were performed in accordance to APHA 3112B.

- Organic compounds analysis.

In each analysis, a $100 \mathrm{ml}$ sample was extracted with $300 \mathrm{ml}$ of hexane; the aqueous layer was discarded, and the collected hexane was evaporated to $1 \mathrm{ml}$ by using a rotary evaporator; then, a 1.0 micro-litre of sample was injected into the GCMS with a temperature programme from $35^{\circ} \mathrm{C}-250^{\circ} \mathrm{C}$ at $10^{\circ} \mathrm{C} / \mathrm{min}$ (Column specification: $30 \mathrm{~m}, 0.25 \mathrm{~mm}, 0.25 \mathrm{um}$ ). There are two analysis assumptions in this experiment; firstly, density of hexane extract is considered to be $1.0 \mathrm{~g} / \mathrm{ml}$; secondly, all phenol derivatives were detected as phenol in the standard method for phenol determination according to APHA 5530D. 


\section{B. Exhaust gas measurement}

In this experimental fieldwork, wood chips and Balingian-Mukah coal were used as feedstock. The amount of wood chips and Balingian-Mukah coal used in this experiment are approximately $130 \mathrm{~kg}$, respectively. During operation, samples for combustible fuel gas were collected at the exhaust (tail pipe effluent) point of the B2F and at nearby areas ( $<20$ meters radius from emission source) for chemical compounds, including $\mathrm{CO}, \mathrm{CH}_{4}$, volatile organic compounds and suspended particulate matters. A sample was extracted with $2 \mathrm{ml}$ of hexane; the aqueous layer was discarded, and the collected hexane was evaporated to $1 \mathrm{ml}$ by using a rotary evaporator; then, a 1 micro-litre of sample was injected into GCMS with a temperature programme from $45^{\circ} \mathrm{C}-250^{\circ} \mathrm{C}$ at $5^{\circ} \mathrm{C} / \mathrm{min}$ (Column specification: $30 \mathrm{~m}, 0.25 \mathrm{~mm}, 0.25 \mathrm{um}$ ).

\section{RESULT AND DISCUSSION}

\section{A. Characteristics of Condensate AFRL}

Table 1 shows that some of the inorganic and heavy metals contained in the condensate (AFRL) were not in compliance with Malaysia's sewage and industrial effluent discharge standards (Environmental Quality Act, 1974), with the inclusion of cadmium $(0.08 \mathrm{mg} / \mathrm{L})$, nickel $(1.0 \mathrm{mg} / \mathrm{L})$ and lead $(1.73 \mathrm{mg} / \mathrm{L})$. The finding in this work is in agreement with [12], which used vineyard residues as a fuel for domestic boilers. Ireland's results showed that a mixture of coal and sewage sludge combustion produced a higher concentration than a wood chip sample in terms of $\mathrm{As}, \mathrm{Cd}, \mathrm{Cr}, \mathrm{Cu}, \mathrm{Ni}, \mathrm{Pb}, \mathrm{Se}$ and $\mathrm{Zn}$ [9]. The level of phenol contained in the AFRL measured as high as 5,310 mg/L, which exceeded the $0.001 \mathrm{mg} / \mathrm{L}$ limit and did not comply with the standard. Thus, one of the reasons for this result is due, mainly, to the sample's contamination [13].

Table 1: Inorganics and heavy metals in AFRL as compared to Standard A and Standard B (wood chips as feedstock)

\begin{tabular}{|l|c|c|c|c|}
\hline Parameter & $\begin{array}{c}\text { Concentration } \\
\text { in AFRL } \\
\text { (mg/L) }\end{array}$ & $\begin{array}{c}\text { Standard } \\
\mathbf{A} \\
(\mathbf{m g} / \mathbf{L})\end{array}$ & $\begin{array}{c}\text { Standard } \\
\text { B } \\
(\mathbf{m g} / \mathbf{L})\end{array}$ & $\begin{array}{c}\text { Mixture of coal } \\
\text { and sewage } \\
\text { sludge [9] }\end{array}$ \\
\hline Silver, Ag & 0.005 & N/A & N/A & \\
\hline Arsenic, As & $<0.007$ & 0.05 & 0.10 & $19-20$ \\
\hline Boron, B & 119 & 1.0 & 4.0 & \\
\hline Barium, B & 0.29 & N/A & N/A & \\
\hline $\begin{array}{l}\text { Beryllium, } \\
\text { Be }\end{array}$ & 0.0008 & N/A & N/A & \\
\hline Cadmium, Cd & 0.08 & 0.01 & 0.02 & $2-3$ \\
\hline Cobalt, Co & 0.18 & N/A & N/A & \\
\hline $\begin{array}{l}\text { Chromium, } \\
\text { Cr }\end{array}$ & 0.77 & N/A & N/A & $21-32$ \\
\hline Copper, Cu & 0.04 & 0.20 & 1.0 & $53-120$ \\
\hline Iron, Fe & $0.375 \%$ & 1.0 & 5.0 & \\
\hline $\begin{array}{l}\text { Molybdenum, } \\
\text { Mo }\end{array}$ & $<0.001$ & N/A & N/A & \\
\hline Mercury, Hg & 0.001 & 0.005 & 0.05 & \\
\hline Nickel, Ni & 1.0 & 0.20 & 1.0 & $30-32$ \\
\hline Lead, Pb & 1.73 & 0.10 & 0.5 & $43-110$ \\
\hline Antimony, Sb & 0.11 & N/A & N/A & \\
\hline Selenium, Se & 0.06 & N/A & N/A & \\
\hline Thallium, TI & 0.11 & N/A & N/A & \\
\hline Vanadium, V & $<0.001$ & N/A & N/A & \\
\hline Zinc, Zn & 18 & 2.0 & 2.0 & $104-235$ \\
\hline Phenol & & 0.001 & 1.0 & \\
\hline
\end{tabular}

Note * Standard A and Standard B refer to the parameter limits of effluent set in Environmental Quality (Sewage and Industrial Effluents) regulation, 1979 [14] *N/A means Not Available

\section{B. Combustible Fuel Gases and Suspended Particulate Matters}

Analysis results of the raw (unburnt) combustible fuel gases from low grade Balingian-Mukah coal and wood chips as feedstock are summarised in Table 2. It was found that there were approximately 23-29\% gasoline constituents; $15-30 \%$ diesel constituents; $1-16 \% \mathrm{CO}_{2} ; 10-13 \% \mathrm{O}_{2}, \mathrm{CO}, \mathrm{SO}, \mathrm{NO}$ and $\mathrm{H}_{2} \mathrm{O} ; 46-71 \%$ combustible gases. This result shows that the $\mathrm{B} 2 \mathrm{~F}$ converter is suitable to harvest the combustible gases that can be used as fuel for internal combustion engines [15].

During operation, nearby (with a 20 meter radius) incremental pollutant levels measured $25-40 \mathrm{ppm} \mathrm{CO}, 6-10 \mathrm{ppm} \mathrm{H}_{2} \mathrm{~S}, 80-$ $110 \mu \mathrm{g} / \mathrm{m}^{3}$ total suspended particulates and $<30 \mu \mathrm{g} / \mathrm{m}^{3}$ PM10 and ash and charcoal (negligible amount); $10-13 \% \mathrm{H}_{2} \mathrm{O}$ 


\section{UNIMAS e-Journal of Civil Engineering: Volume 5, Issue 1}

condensate; $1-2 \%$ tars (Table 2). Results from Table 2 indicate the produced air pollution was under the optimum condition [16], [17] and [18].

Table 3 shows the primary composition of exhaust gas; specifically, wood chips as feedstock recorded approximately $3.5 \%$ $\mathrm{O}_{2}, 16.1 \% \mathrm{CO}_{2},>10,000 \mathrm{ppm} \mathrm{CO}, 271 \mathrm{ppm} \mathrm{NO}$ and $190 \mathrm{ppm}$ SO. However, the key composition of exhaust gas from Balingian-Mukah coal as feedstock measured 9.3\% $\mathrm{O}_{2}, 10.1 \% \mathrm{CO}_{2},>10,000 \mathrm{ppm} \mathrm{CO}, 65 \mathrm{ppm} \mathrm{NO}$ and $25 \mathrm{ppm} \mathrm{SO}$. It was shown that coal as feedstock of a B2F converter produced relatively less pollutants in the exhaust gas, when compared to wood chips.

Table 2: Summary of unburnt combustible gas compositions and nearby incremental air pollutant generated by BalingianMukah coal and wood chips during operation

\begin{tabular}{|c|c|}
\hline Fuel gases & Results \\
\hline $\begin{array}{l}\text { Unburnt combustible } \\
\text { gas composition }\end{array}$ & $\begin{array}{l}\text { Approximately } 23-29 \% \text { gasoline constituents } \\
15-30 \% \text { diesel constituents } \\
8-12 \% \text { poly-aromatics } \\
1-16 \% \text { carbon dioxide }\left(\mathrm{CO}_{2}\right) \\
10-13 \% \text { of } \mathrm{O}_{2}, \mathrm{CO}, \mathrm{SO}, \mathrm{NO} \& \mathrm{H}_{2} \mathrm{O} \\
46-71 \% \text { combustible gases (i.e. gasoline, diesel constituents and poly-aromatics) }\end{array}$ \\
\hline $\begin{array}{l}\text { Nearby incremental } \\
\text { air pollutant }\end{array}$ & $\begin{array}{l}25-40 \mathrm{ppm} \mathrm{CO} \\
6-10 \mathrm{ppm} \mathrm{H}_{2} \mathrm{~S} \\
80-110 \mu \mathrm{g} / \mathrm{m}^{3} \text { total suspended particulates and }<30 \mu \mathrm{g} / \mathrm{m}^{3} \mathrm{PM} 10 \\
\text { Negligible ash and charcoal } \\
10-13 \% \mathrm{H}_{2} \mathrm{O} \text { condensate } \\
1-2 \% \text { tars }\end{array}$ \\
\hline
\end{tabular}

Table 3: Analysis of exhaust gas (combustion by-products of combustible fuel gas)

\begin{tabular}{|l|c|c|c|c|c|c|c|}
\hline $\begin{array}{l}\text { Fuel } \\
\text { (Feedstock) }\end{array}$ & $\begin{array}{c}\text { Oxygen } \\
\%\end{array}$ & $\begin{array}{c}\mathbf{C O}_{\mathbf{2}} \\
\mathbf{\%}\end{array}$ & $\begin{array}{c}\text { CO } \\
\mathbf{p p m}\end{array}$ & $\begin{array}{c}\text { NO } \\
\mathbf{p p m}\end{array}$ & $\begin{array}{c}\mathbf{N O}_{2} \\
\mathbf{p p m}\end{array}$ & $\begin{array}{c}\mathbf{N O}_{\mathbf{X}} \\
\mathbf{p p m}\end{array}$ & $\begin{array}{c}\text { SO } \\
\mathbf{p p m}\end{array}$ \\
\hline Wood chips & 3.5 & 16.1 & $>10,000$ & 271 & N.D & 271 & 190 \\
\hline Coal & 9.3 & 10.1 & $>10,000$ & 65 & N.D & 65 & 25 \\
\hline \multicolumn{7}{|c|}{ *N.D means Not Detected }
\end{tabular}

\section{CONCLUSIONS}

This study presents the results of an operational parameters assessment on a B2F converter, from which the following conclusions can be drawn. Analysis results of the raw (unburnt) combustible fuel gases from low grade Balingian-Mukah coal and wood chips found that there were approximately 23-29\% gasoline constituents; $15-30 \%$ diesel constituents; $1-16 \%$ $\mathrm{CO}_{2} ; 10-13 \% \mathrm{O}_{2}, \mathrm{CO}, \mathrm{SO}, \mathrm{NO}$ and $\mathrm{H}_{2} \mathrm{O} ; 46-71 \%$ combustible gases. The level of phenol contained in the AFRL measured as high as $5,310 \mathrm{mg} / \mathrm{L}$, which exceeded the $0.001 \mathrm{mg} / \mathrm{L}$ limit; therefore, it does not comply with the Standard A and Standard B established under the Environmental Quality (Sewage and Industrial Effluents) Regulations, 1979. Approximately 1.5\% tars and 13\% AFRL were produced as by-products. The result shows that the B2F converter is suitable to harvest the combustible gases that can be used as fuel for internal combustion engines. However, the amount of organics indicated that the AFRL should not be discharged directly into watercourses without pre-treatment.

\section{ACKNOWLEDGMENT}

The authors acknowledge the financial support provided by Prima Natural Resources and Manufacturing Sdn. Bhd. and Zamalah Siswazah UNIMAS.

[1] MTC, "Malaysia: Forestry \& environment (facts \& figures)," MTC, 01-May-2009. [Online]. Available: http://forestry.oupjournals.org/cgi/doi/10.1093/forestry/74.5.499.

[2] A. Bauen, J. Woods, and R. Hailes, "A biomass blueprint to meet 15\% of OECD electricity demand by 2020," Imperial College London, 2004 [Online]. http://scholar.google.com/scholar?hl=en\&btnG=Search\&q=intitle:A+BIOMASS+BLUEPRINT+TO+MEET+15+\%+OF+OECD+ELECTRICITY+D EMAND+BY+2020\#0. [Accessed: 10-Dec-2013].

[3] S. Ahmad, M. Z. A. A. Kadir, and S. Shafie, "Current perspective of the renewable energy development in Malaysia," Renew. Sustain. Energy Rev., vol. 15 , no. 2, pp. 897-904, Feb. 2011

[4] "APEC Energy Demand and Supply Outlook." [Online]. Available: http://aperc.ieej.or.jp/publications/reports/outlook.php.

[5] A. T. Ali, "Securing a sustainable energy future for Malaysia," 2011. 


\section{UNIMAS e-Journal of Civil Engineering: Volume 5, Issue 1}

[6] P. R. Wander, C. R. Altafini, and R. M. Barreto, “Assessment of a small sawdust gasification unit," Biomass and Bioenergy, vol. 27, no. 5, pp. 467476, Nov. 2004.

[7] W. Walawender, S. M. Chern, and L. T. Fan, "Wood Chip Gasification in a Commercial Downdraft Gasifier," in Fundamentals of Thermochemical Biomass Conversion SE - 50, R. P. Overend, T. A. Milne, and L. K. Mudge, Eds. Springer Netherlands, 1985, pp. 911-921.

[8] P. Garcia-Bacaicoa, R. Bilbao, J. Arauzo, and M. L. Salvador, "Scale-up of downdraft moving bed gasifiers (25-300 kg/h) - Design, experimental aspects and results," Bioresour. Technol., vol. 48, no. 3, pp. 229-235, 1994.

[9] S. N. Ireland, B. Mcgrellis, and N. Harper, "On the technical and economic issues involved in the co-firing of coal and waste in a conventional pffired power station," Fuel, vol. 83, no. 7-8, pp. 905-915, May 2004.

[10] T. Nussbaumer, "Combustion and Co-combustion of Biomass: Fundamentals, Technologies, and Primary Measures for Emission Reduction †," Energy \& Fuels, vol. 17, no. 6, pp. 1510-1521, Nov. 2003.

[11] I. Calleja, L. Delgado, P. Eder, A. Kroll, J. Lindblom, C. Van Wunnik, O. Wolf, F. Gouarderes, and J. Langendorff, "Promoting environmental technologies: sectoral analyses, barriers and measures," 2004.

[12] G. Picchi, S. Silvestri, and A. Cristoforetti, "Vineyard residues as a fuel for domestic boilers in Trento Province (Italy): Comparison to wood chips and means of polluting emissions control," Fuel, vol. 113, pp. 43-49, Nov. 2013.

[13] J. Krook, a Mårtensson, and M. Eklund, "Sources of heavy metal contamination in Swedish wood waste used for combustion.," Waste Manag., vol. 26, no. 2, pp. 158-66, Jan. 2006.

[14] “SEWAGE AND INDUSTRIAL EFTLUENTS REGULATIONS , 1979,” 1979.

[15] A. K. Rajvanshi, "Biomass gasification," in Alternative Energy in Agriculture, vol. II, no. 4, Maharashtra: CRC Press, 1986 , pp. 82-102.

[16] NIOSH, "NIOSH Pocket Guide to Chemical Hazards - Carbon monoxide," 2011. [Online]. Available: http://www.cdc.gov/niosh/npg/npgd0105.html. [Accessed: 11-Feb-2014].

[17] NIOSH, "NIOSH Pocket Guide to Chemical Hazards - Hydrogen sulfide," 2011. [Online]. Available: http://www.cdc.gov/niosh/npg/npgd0337.html.

[18] EPA, "Particulate Matter (PM-10)," 2012. [Online]. Available: http://www.epa.gov/airtrends/aqtrnd95/pm10.html. 